\title{
Assessing the determinants of household electricity prices in the EU: a system-GMM panel data approach
}

\author{
Patrícia Pereira da Silva ${ }^{\mathrm{a}, \mathrm{b}, \mathrm{d}, *}$, Pedro A. Cerqueira ${ }^{\mathrm{a}, \mathrm{c}, \mathrm{d}}$ \\ ${ }^{a}$ Faculty of Economics - University of Coimbra Av. Dias da Silva, 165, 3004-512 Coimbra, Portugal \\ b INESC Coimbra, Rua Sílvio Lima, Pólo II 199, 3030-030 Coimbra, Portugal \\ c GEMF, Grupo de Estudos Monetários e Financeiros, Coimbra, Portugal \\ ${ }^{\mathrm{d}}$ CeBER, Centre for Business and Economics Research, Av. Dias da Silva, 165, 3004.512, Coimbra Portugal
}

\section{A R T I C L E I N F O}

\section{JEL codes:}

Q28

Q48

C33

\section{Keywords:}

Household electricity prices

Market liberalization

Renewable energy

System-GMM panel data model

\begin{abstract}
A B S T R A C T
A meaningful portion of the consumer basket of European households and companies is embodied by electricity as well as gas or refined petroleum products. As energy products are essential inputs of nearly all final goods and services, whichever change of energy prices has a direct impact of the general price level. In this context, the main purpose of this study is to assess the main drivers of household electricity prices in the European Union (EU), throughout a period of deep sector transformation. Relying on Eurostat data, not only we analyze the long-term progress of household electricity prices across the EU, but also we provide empirical evidence on their determinants while confronting the results with the EU energy policy path. For this purpose a firsthand approach is herein developed based on a dynamic model with panel data through GMM proposal method by Blundell and Bond (1998) [4] with the Windermeijer (2005) [41] correction. The data analysis provides grounds for a relation between the variable of household electricity prices with variables related to sector liberalization, renewable energy sources which support the EU policy to boost liberalization. This study offers evidence that the sector liberalization is accompanied by a decreasing trend in prices, which is consistent with the European Commission's objectives to liberalize.
\end{abstract}

\section{Introduction}

Generally, microeconomic theory recommends that competition and the profit drive result in internal (production) and external (market) efficiency and that the benefits are passed on to customers and the economy in the form of lower prices and costs.

Recently, however, in the context of electricity markets, the overall wisdom of the European Union (EU) ambition towards more competition and more open energy markets and what concrete benefits were brought to end consumers by this policy have been questioned [8].

Already almost a decade ago and according to several authors, it is possible to acknowledge that European electricity market liberalization represents the world's most extensive cross-jurisdiction reform of the electricity sector involving integration of distinct state-level or national electricity markets. Electricity sector liberalization is part of the wider trend toward liberalization and wishes on the withdrawal of the state from involvement in infrastructure industries [26].

Given the strategic position of the electricity industry in national politics, in the absence of policy at the level of the European Union (EU), the pace of reform in many member states would have been considerably slower, in spite of several criticism concerning the long process behind the building of the internal energy market.

Although the performance of liberalization can be measured in a number ways, the effect on electricity prices is believed to be, by Jasmab and Pollit [26], the single most important performance indicator. A desirable outcome of the single European market was to achieve a lower average EU price and a degree of price convergence through wholesale and retail competition.

In this context, a more recent study by Cruciani [8] is to mention, aligned with results from Coppens and Vivet [6]. Cruciani [8] argument starts with the observation that electricity prices for domestic and industrial users have increased significantly since 1998, the year that marks the opening of the EU electricity markets. The charts in Figs. 1 and 2 illustrate this by presenting the case of the German median domestic consumers who saw their electricity bills increase by more than $60 \%$ in the observed period [14].

European Commission documents also state that the aim of the EU energy policy was "to ensure that EU consumers receive the full benefits of market opening in terms of lower domestic bills for electricity and gas", but Cruciani [8] concludes that, more than 10

\footnotetext{
* Corresponding author at: Faculty of Economics - University of Coimbra Av. Dias da Silva, 165, 3004-512 Coimbra, Portugal.

E-mail address: patsilva@fe.uc.pt (P.P. da Silva).
} 


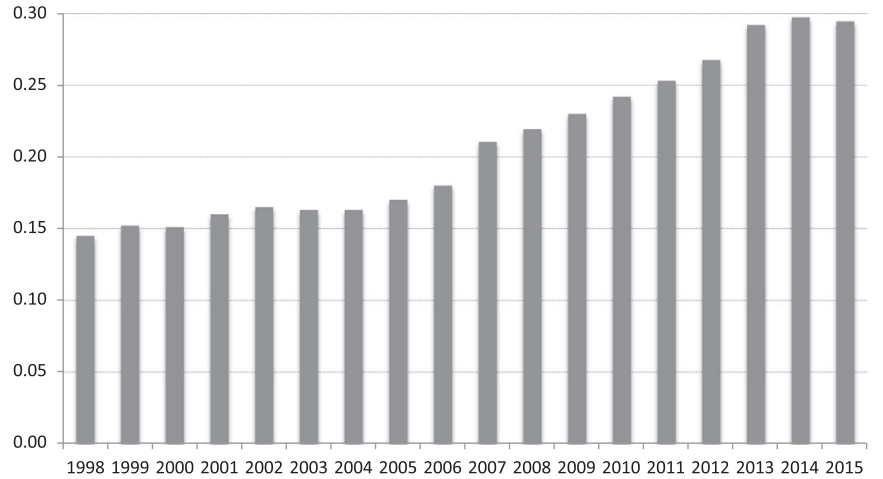

Fig. 1. - German retail electricity prices for domestic consumers (nominal prices, all taxes included, in Eur/kWh). Note: Prior to 2007 the following Eurostat end consumer categories were used: Households - Dc (Annual consumption: $3500 \mathrm{kWh}$ of which night 1300).

Source: Eurostat

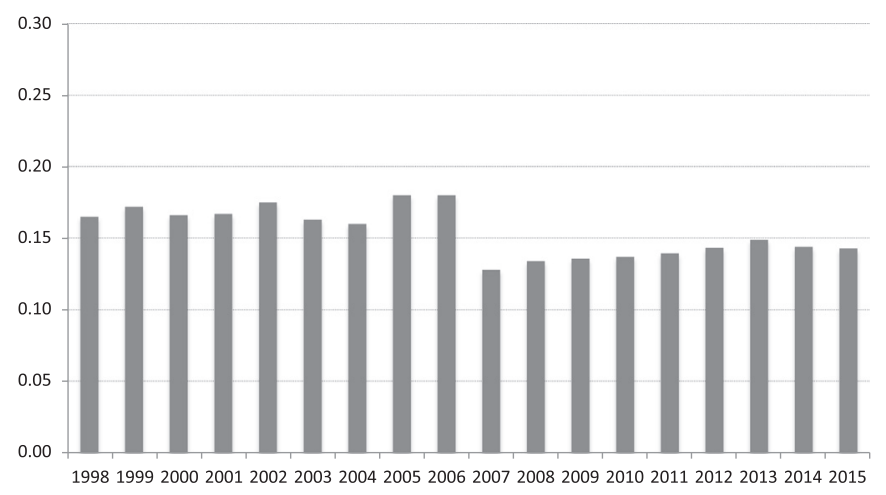

Fig. 2. - German retail electricity prices for domestic consumers (prices in 2005 EUR, all taxes excluded, in Eur $/ \mathrm{kWh}$ ). Note: Prior to 2007 the following Eurostat end consumer categories were used: Households - Dc (Annual consumption: $3500 \mathrm{kWh}$ of which night 1300).

Source: Eurostat

years after the opening of the markets, the liberalization has not delivered tangible benefits to consumers.

An additional set of issues raised by electricity deregulation (or reregulation, as some might prefer), could influence the final outcome. The foremost problems are related to the unusual characteristics of "electricity" as a product, which make the industry very different from other network industries: electricity is not storable, demand and supply must be constantly balanced, and demand is both volatile and inelastic $[27,36]$.

Jamasb et al. [25], using a three broad category to classify approaches to analyze electricity reforms (econometric methods, efficiency and productivity analysis methods, and individual or comparative case studies), argue that econometric studies are best suited to the analysis of well-defined issues and the testing of hypotheses through statistical analysis of reform determinants and performance. Within this classification, the present study suits the first category.

As underlined by the same authors, there is a lack of generally accepted and measured indicators for monitoring the progress, performance of electricity sector reforms, and, namely, impacts on electricity prices, the main purpose of our article. To our best knowledge, no applied study has been done so far using a system-GMM panel data proposal method by Blundell and Bond [4] with Windermeijer [41] correction (2005) as we herein provide.

The remainder of this study is organized as follows: in Section 2 a brief overview of the evolution of the EU electricity market is provided; Section 3 summarizes previous studies on electricity prices; Section 4 presents the empirical method and data; and Section 5 concludes.

\section{The evolution of the EU electricity market}

Electricity sectors either being European or elsewhere evolved with (primarily) vertically integrated geographic monopolies that were either state-owned or privately-owned and subject to price and entry regulation as natural monopolies. The primary components of electricity supply - generation, transmission, distribution, and retail supply - were integrated within individual electric utilities.

The prevailing reform goal has been to create new institutional arrangements for the electricity sector that provide long-term benefits to society and to ensure that an appropriate share of these benefits are conveyed to consumers through prices that reflect the efficient economic cost of supplying electricity and service quality attributes that reflect consumer valuations.

The European Electricity Supply Industry (ESI) reform was pursued at two parallel levels. First, under EU Electricity Market Directives, member countries were required to take at least a minimum set of steps by certain key dates toward the liberalization of their national markets. Second, the European Commission promoted efforts to improve the interfaces between national markets by improving cross-border trading rules, and to expand cross-border transmission links. The underlying aim of both of these policies was to extend the principles of the European Single Market to the energy market by Directives that would enable companies from across the EU to compete with national incumbents, while improved interconnection would reduce cross-border transport costs and increase competition.

EU legislation in the area of electricity markets (and also gas markets, but that are not the current focus) has evolved over time. The first, second and third EU Electricity Market Directives, commonly referred to as Internal Energy Market Packages, of 1996, 2003 and 2009 focused on unbundling the industry and on a gradual opening of national markets. The key items of legislation for the Second and Third Internal Energy Market packages concerning electricity market liberalization are listed below [15-19] (excluding gas issues).

- Second Internal Energy Market Package:

- Directive 2003/54/EC of 26 June 2003 on internal market in electricity, and

- Regulation 1228/2003 of 26 June 2003 on access for cross-border exchanges in electricity.

- Third Internal Energy Market Package:

- Directive 2009/72/EC of 13 July 2009 on internal market in electricity (repeals 2003/54/EC), and

- Regulation 714/2009 of 13 June 2009 on access for cross-border exchanges in electricity (repeals 1228/2003).

The structure of the packages is based on a directive and a regulation for electricity market liberalization. Each of these two items of legislation of the Second Internal Energy Market package is repealed by corresponding directives and regulations in the Third Internal Energy Market package. The latter also establishes an Agency for the Cooperation of Energy Regulators (ACER) through Regulation 713/2009.

The legislative acts from the Second Internal Energy Market Package were included in the Energy Community Treaty in October 2005. The members committed to transposing these acts into national legislation by 1 July 2007. Members also committed to fully opening electricity markets to non-household customers by 1 January 2008, and to fully opening both markets to all customers by 1 January 2015. This process offers a clear timeframe and specifically defined milestones for the members of the Energy Community to liberalize their electricity (and gas) markets, as well as for the Energy Community Secretariat, the European Commission and other observers to monitor and assess progress in transposing and 
applying the legislation. Economic effects are expected to take place only after the legal implementation. Therefore we may look at the liberalization as a sequential process, whereby national implementation leads to effects on market actors and market structures, on prices, and in consequence to employment effects. (see [32] for a more extensive review on the progress of European energy). Deviations from the initial timeframe have occurred at the level of transposition into national law (e.g. national parliaments delay or try to amend or block the legislation, or on the contrary accelerate its adoption), or at the level of its entry into force (which could be delayed or on the contrary brought forward), or at the level of its implementation by the corresponding regulatory authorities.

As of the end of 2011, many of the Member States continue to regulate retail prices, especially for households, and only allow an appreciation that is no bigger than the rise of the general price level.

In a way, this could explain the alignment of retail prices for electricity and inflation.

Considering the contribution of renewable energy sources (hereafter, RES) in the electricity market, a polemic debate has arisen about its effects on household electricity prices. A superior use of renewable energies could reduce the wholesale electricity prices as they are characterized by lower variable costs than fossil conventional technologies. Nonetheless, the development of RES is predominantly compelled by public renewable support schemes that are financed via the electricity market by increasing the final price paid by consumers. For instance, Amorim et al., [2], referring to the Portuguese electricity supply industry, provided evidence that the volume and the duration of the existing legacy contracts, including special incentives and guaranteed purchase prices granted to special regime (SR) generators - i.e. generators based on RES, waste and combined heat and power or cogeneration (CHP) prevents the development of a competitive wholesale market at least until the mid 2020s and, thus, price guarantees represent costs to be paid by electricity consumers during the next decades.

Also, the European Union Emission Trading Scheme (EU ETS), which was launched in 2005 and has started its third phase in the beginning of 2013, has had an impact on electricity spot prices and eventually on household prices as mentioned by Freitas and Pereira da Silva [21,22]. In that sense, the replacement of conventional electricity generation with renewable energy sources could decrease the cost originated from environmental emissions and accordingly the electricity price. Consequently, both the development made towards the electricity market liberalization and also the increased contribution of RES into the market are critical elements to the clarifications of final electricity prices paid by consumers.

\section{Review of earlier studies}

One of the earliest analyses of the reform process and electricity prices is the empirical analysis by Steiner [38], as previously stated by Erdogdu $[10,11]$. Steiner [38] studied the effect of regulatory reforms on the retail prices for large industrial customers as well as the ratio of industrial price to residential price, using data for 19 OECD countries for the period 1986-1996. In her study, Steiner [38] carried out a panel data analysis including electricity price, ratio of industrial to residential electricity price, capacity utilization rate and reserve margin. Using these variables, she tried to measure the competitive aspects and the cost efficiency of reform. As main conclusions, the study found that electricity market reforms generally induced a decline in the industrial price and an increase in the price differential between industrial customers and residential customers, indicating that industrial customers benefit more from the reform. It was also found that unbundling is not associated with lower prices but is associated with a lower industrial to residential price ratio and higher capacity utilization rates and lower reserve margins.

Hattori and Tsutsui [23] examined the impact of the regulatory reforms on prices in the electricity industry. Comparable to Steiner [38], they also used panel data for 19 OECD countries but for the period 1987-1999. Hattori and Tsutsui [23] indicated that, first, expanded retail access is likely to lower the industrial price, while at the same time increasing the price differential between industrial and household customers. Second, they concluded that the unbundling of generation did not necessarily lower the price and may have possibly resulted in higher prices. Like Steiner [38], their estimation showed that the effect of unbundling on the level of industrial price is statistically insignificant. Besides, they found that the introduction of a wholesale power market did not necessarily lower the price, and may indeed had resulted in a higher price.

Pollitt [34] mentions two other empirical studies that examine the price impacts of reform by Ernst \& Young [13] and Thomas [40]. Ernst \& Young [13] prepared a report for the UK government's Department of Trade and Industry (DTI). Using a sample of EU-15 countries they tried to produce some policy suggestions for electricity and gas industries with a large number of simple regressions. As a result of their consultancy report, they concluded that liberalization lowers prices; liberalization lowers costs and price-cost margins; liberalized markets increase price volatility; liberalization inhibits investment; liberalized markets provide reliable and secure supply; and liberalized markets interact effectively with other public policies (such as on climate change). Thomas [40] examined a number of reports including those of European Commission, which are related to electricity prices. He argued although these studies suggest that reforms in the EU have been associated with lower prices for consumers, the evidence does not support these assertions. The price reductions, he continued, that have occurred in the past decade took place mostly in the period 1995-2000, before liberalization was effective in most of the European Union and since then, prices have risen steeply, in many cases wiping out the gains of the earlier period. Other factors, not properly accounted for, such as fossil fuel price movements, technological innovations and changes to regulatory practices were more likely to have led to the price reductions that occurred in the period 1995-2000 than reforms that had not then taken effect.

Nagayama [30] used panel data for 83 countries covering the period 1985-2002 to examine how each policy instrument of the reform measures influenced electricity prices for countries in Latin America, the former Soviet Union, and Eastern Europe. The research findings suggested that neither unbundling nor introduction of a wholesale pool market on their own necessarily reduces the electricity prices. In fact, contrary to expectations, there was a tendency for the prices to rise. He argued, however, coexistent with an independent regulator, unbundling may work to reduce electricity prices. Nagayama [31] aimed at clarifying whether the effects of electric power sector reforms should be different either across regions, or between developing and developed countries. He analyzed an empirical model to observe the impact of electric power prices on the selection of a liberalization model in the power sector. This was achieved by the use of an ordered response, fixed effect and a random effect model. An instrument variable technique was also used to estimate the impact of the liberalization model on the electric power price. The research findings suggested that higher electricity prices are one of the driving forces for governments to adopt liberalization models, a finding also noted by Joskow [27], in the context of the US. However, the development of liberalization models in the energy sector does not necessarily reduce electricity prices. In fact, contrary to expectations, the study found that there was a tendency for the prices to rise in every market model.

Considering electricity prices and survey data on consumer satisfaction in the EU-15, the empirical findings by Fiorio [19], rejected the prediction that privatization leads to lower prices, or to increased consumer satisfaction. They also found that country specific features tend to have a high explanatory power, and the progress toward the reform paradigm is not systematically associated with lower prices and higher consumer satisfaction.

As earlier emphasized in the introduction, Cruciani [8] shows that the liberalization of electricity markets in the EU 'has not had a major effect on prices', results that are contrary to what the European Commission has always aimed. He also shows that opening up and connecting markets 
does not necessarily lead to a more efficient system.

More recently, Florio [20] described the impact of the EU-15 energy reforms on household energy prices between 1990 and 2007, therefore not including the Third Package EU directives, through panel models. Fundamentally, it was found that household electricity prices are lower in countries with state-owned utilities operating in the market. Moreover, unbundling of the electricity sector was not proven to have a significant influence on household electricity price, however the freedom to choose electricity supplier is valued by consumers, resulting or not in lower prices. Household electricity prices are also reported to have increased in Lithuania and Poland, with two different approaches to liberalization [39], whilst electricity market opening for households in Lithuania was achieved in 2007, in Poland electricity prices are still under a regulated tariff. In Germany, Dillig et al.[9] established, on the contrary, that consumers gained with the deployment of renewables, estimating a net saving of 11,2 billion Euros in 2013.

The ACER 2014 annual internal electricity market monitoring report shows a general increasing trend in household electricity prices. In spite of the decreasing wholesale electricity prices, mainly due to the so called "merit order effect" $[3,42]$, the "non-contestable charges" growth are attributed to be the main cause of retail electricity prices increase [1]. These "non-contestable charges" were largely contested due to the contributing growth in renewable deployment incentives and the financial crisis in some European countries, like Spain and Italy [7]. Furthermore, renewables benefits associated with carbon emissions and fossil-fuel savings, were found broadly to be lower than the support costs in the EU-28 [33]. However, technology-wise, hydro and wind benefits outweigh the respective policy costs, whilst photovoltaics and less mature renewables remain a high cost burden to consumers.

\section{Empirical study}

This section describes the empirical study and the results obtained. The first subsection describes the data used and the second shows the model specification and the estimation results.

\subsection{Data}

The data herein presented was retrieved from the databases containing the most precise information, the most constant over time and the most homogenized among European Member-States, which belong to the European Commission, managed by Eurostat. Because the values on electricity prices to the industry remain contestable, as contracts with industry often include confidential clauses, the present study only deals with household prices excluding taxes and levies. However, it is important to highlight that because Eurostat introduced a methodological break in the series in 2007, it was only possible to obtain series comprising one area of acceptable approximations between 2000 and 2014 for the 23 out of 27 European Member States. ${ }^{1}$

The variables used were the electrical price $(E p)$ as described before and as explanatory variables, retrieved for the same countries, from 2000 to 2014 and from the same sources (except when stated otherwise), were: the electric household consumption in tons of oil equivalent per capita ( $E C H p c)$ and the real GDP per capita (GDPpC) measured in thousands of Euros, to control for demand factors. The gas price measured in $\$ / \mathrm{mmBtu}^{2}(G A S p)$, the electricity production of renewable sources as share of the overall gross electric consumption (RESe), the greenhouse gas emission in thousands of tonnes per capita (GGEpC), to control for supply factors. And to access the effect of market liberalization we included the share of the largest electric producer as share of the total production $(E C G)$, the date of market

\footnotetext{
${ }^{1}$ The countries included were: Belgium, Czech Republic, Denmark, Germany, Estonia, Ireland, Greece, Spain, France, Italy, Cyprus, Latvia, Lithuania, Hungry, Malta, Poland, Portugal, Romania, Slovenia, Slovakia, Finland, Sweden and the United Kingdom.

2 Taken from the BP Statistical Review of World Energy, June 2016.
}

Table 1

Descriptive statistics of the variables.

\begin{tabular}{llllll}
\hline Variable & Obs & Mean & Std. Dev. & Min & Max \\
\hline Ep & 325 & 0.107 & 0.033 & 0.046 & 0.234 \\
GDPpc & 345 & 21,457 & 11,237 & 3700 & 46,200 \\
ECHpc & 345 & 0.140 & 0.080 & 0.029 & 0.422 \\
GGEpc & 345 & 10.252 & 3.110 & 4.410 & 19.200 \\
GASp & 345 & 7.285 & 2.954 & 2.910 & 11.601 \\
ECG & 337 & 0.586 & 0.277 & 0.153 & 1.000 \\
RESE & 345 & 0.178 & 0.152 & 0 & 0.633 \\
REG10 & 345 & 0.696 & 0.461 & 0 & 1 \\
LIB & 345 & 0.568 & 0.496 & 0 & 1 \\
\hline
\end{tabular}

liberalization ${ }^{3}(\mathrm{Lib})$ and if the country still had regulated prices in 2010 $(\operatorname{Reg} 10){ }^{4}$

Finally, we should note that the electricity price and the ECG variables are not available for the entire data span (2000-2014) in all countries leading to an unbalanced panel. Description of data availability, as the date of market liberalization and if the country still had a regulated electric price in 2010 is described in the Appendix A.

Table 1 presents the variables descriptive statistics.

\subsection{Estimation methodology and results}

In this study, we have a dynamic panel data model of lagged levels of the dependent variables and consequently we use the Blundell and Bond [4] two-step system GMM methodology with the Windermeijeir (2005) errors correction. This methodology is justified on the basis that traditional fixed effects estimator is biased in the presence of the lagged dependent variable as regressor and it also accounts for possible endogeneity of some of the dependent variables.

We should remark that alternative consistent estimators with lagged dependent variable, such as the one of Bruno [5], are only valid when the explanatory variables are strictly exogenous. In our model we consider that the GDPpc, ECHpc. GGEpc and RESe are endogenous as these also respond to the variations on the electricity price and that $G A S p$ and $E C G$ variables are, at least, pre-determined.

Moreover, as Soto [37] reveals, the system-GMM presents the lowest bias and highest precision when the $\mathrm{N}$ dimension in the panel (in our case the number of countries) is small and the series are moderately or highly persistent, when compared to other widely used estimators: the fixed effect or the difference GMM. ${ }^{5}$

The estimated model, taking the logarithm of the household electrical price, l.ep, as dependent variable is:

l. $e p_{i t}=\alpha+\delta$ l. $e p_{i t-1}+\beta X_{i t}+\sum_{k=2000}^{2014} \gamma_{k} d_{k t}+\varepsilon+\mu_{i t}$,

with $|\delta|<1$ and $d_{k t}$ a time-dummy that takes the value 1 when $\mathrm{k}=\mathrm{t}$ and 0 otherwise.

The disturbances $\mu_{i t}$ and $\varepsilon_{i}$ are not cross-correlated and have the standard properties:

\footnotetext{
${ }^{3}$ The variable took the value 0 before the year of liberalization and 1 afterwards. In countries where the liberalization occurred at July, the variable took the value 0 as the price was measured during the first semester. Sources: Eurostat ERCEG 2010 and ACER Market Monitoring Report2015.

${ }^{4}$ The variable took the value 0 for countries that did not have regulated prices after 2010 and 1 otherwise. We used this variable instead of the exact end date of regulated prices because before 2010 it is difficult to extract the exact dates from the official reports. Sources: Eurostat ERCEG 2010 and ACER Market Monitoring Report2015.

5 Therefore, this methodology may provide new insights when compared with the results of Moreno et al. [29], as were the cases of Hyland [24] which studied the impact of the EU restructuring process on electricity prices for industrial consumers or Kais and Sami [28] which provided new empirical evidence on the impact of economic growth and energy use on carbon emissions.
} 
Table 2

Model estimation results.

\begin{tabular}{|c|c|c|c|c|c|c|c|c|c|c|}
\hline & (1) & (2) & (3) & (4) & (5) & (6) & (7) & (8) & (9) & (10) \\
\hline Const. & $-3.991(0.111)$ & $\begin{array}{l}-4.073^{* *} \\
(0.020)\end{array}$ & $\begin{array}{l}-3.93^{* * *} \\
(0.007)\end{array}$ & $\begin{array}{l}-4.092^{* * *} \\
(0.002)\end{array}$ & $\begin{array}{l}-3.766^{* *} \\
(0.011)\end{array}$ & $\begin{array}{l}-2.442^{*} \\
(0.094)\end{array}$ & $\begin{array}{l}-2.489 \\
(0.113)\end{array}$ & $\begin{array}{l}-2.279^{* *} \\
(0.024)\end{array}$ & $\begin{array}{l}-1.948^{* * *} \\
(0.000)\end{array}$ & $\begin{array}{l}-0.720 \\
(0.480)\end{array}$ \\
\hline Lag_l. Ep & $\begin{array}{l}0.767 * * * \\
(0.000)\end{array}$ & $\begin{array}{l}0.771^{* * *} \\
(0.000)\end{array}$ & $\begin{array}{l}0.790 * * * \\
(0.000)\end{array}$ & $\begin{array}{l}0.790 * * * \\
(0.000)\end{array}$ & $\begin{array}{l}\mathbf{0 . 8 0 2}{ }^{* * *} \\
(\mathbf{0 . 0 0 0 )}\end{array}$ & $\begin{array}{l}0.748 * * * \\
(0.000)\end{array}$ & $\begin{array}{l}\mathbf{0 . 8 8 0}{ }^{* * *} \\
(\mathbf{0 . 0 0 0 )}\end{array}$ & $\begin{array}{l}0.780 * * * \\
(0.000)\end{array}$ & $\begin{array}{l}\mathbf{0 . 8 6 7} 7^{* * *} \\
(\mathbf{0 . 0 0 0 )}\end{array}$ & $\begin{array}{l}0.783^{* * *} \\
(0.000)\end{array}$ \\
\hline 1_GDPpc & $0.158(0.510)$ & $\begin{array}{l}0.188 \\
(0.103)\end{array}$ & $0.142(0.349)$ & $\begin{array}{l}0.188^{* *} \\
(0.044)\end{array}$ & $\begin{array}{l}0.177^{*} \\
(0.095)\end{array}$ & - & - & - & - & - \\
\hline 1. ECHpc & - & - & - & - & - & $\begin{array}{l}0.294^{*} \\
(0.051)\end{array}$ & $\begin{array}{l}0.301^{* *} \\
(0.045)\end{array}$ & $\begin{array}{l}0.164^{* *} \\
(0.018)\end{array}$ & $\begin{array}{l}0.164^{* *} \\
(0.012)\end{array}$ & $\begin{array}{l}0.196 * * \\
(0.001)\end{array}$ \\
\hline 1. GASp & $\begin{array}{l}0.678^{* * *} \\
(0.004)\end{array}$ & $\begin{array}{l}0.725^{* * *} \\
(0.000)\end{array}$ & $\begin{array}{l}0.712 * * * \\
(0.000)\end{array}$ & $\begin{array}{l}0.733^{* * *} \\
(0.000)\end{array}$ & $\begin{array}{l}0.655^{* * *} \\
(0.000)\end{array}$ & $\begin{array}{l}0.780^{*} \\
(0.088)\end{array}$ & $\begin{array}{l}1.293^{*} \\
(0.069)\end{array}$ & $\begin{array}{l}0.766^{* *} \\
(0.017)\end{array}$ & $\begin{array}{l}0.924^{* * *} \\
(0.000)\end{array}$ & $\begin{array}{l}0.750^{* * *} \\
(0.000)\end{array}$ \\
\hline 1. GGEpc & $\begin{array}{l}0.134 \\
(0.798)\end{array}$ & - & $\begin{array}{l}0.169 \\
(0.714)\end{array}$ & - & - & $\begin{array}{l}0.336 \\
(0.446)\end{array}$ & - & $\begin{array}{l}0.310 \\
(0.244)\end{array}$ & - & - \\
\hline ECG & $\begin{array}{l}0.000 \\
(0.999)\end{array}$ & $\begin{array}{l}0.014 \\
(0.947)\end{array}$ & $\begin{array}{l}-0.050 \\
(0.892)\end{array}$ & $\begin{array}{l}0.031 \\
(0.891)\end{array}$ & - & $\begin{array}{l}-0.323 \\
(0.437)\end{array}$ & $\begin{array}{l}-0.281 \\
(0.369)\end{array}$ & $\begin{array}{l}-0.372 \\
(0329)\end{array}$ & $\begin{array}{l}-0.158 \\
(0.575)\end{array}$ & - \\
\hline RESe & $\begin{array}{l}1.730^{*} \\
(0.056)\end{array}$ & $\begin{array}{l}1.388^{* * *} \\
(0.004)\end{array}$ & $\begin{array}{l}1.632 * \\
(0.052)\end{array}$ & $\begin{array}{l}1.400^{* * *} \\
(0.000)\end{array}$ & $\begin{array}{l}1.231^{* * *} \\
(0.007)\end{array}$ & $\begin{array}{l}1.487^{*} \\
(0.088)\end{array}$ & $\begin{array}{l}0.976^{* *} \\
(0.044)\end{array}$ & $\begin{array}{l}1.201^{*} \\
(0.059)\end{array}$ & $\begin{array}{l}0.965^{* *} \\
(0.010)\end{array}$ & $\begin{array}{l}1.029 * * \\
(0.041)\end{array}$ \\
\hline Lib & $\begin{array}{l}-0.343 \\
(0.030)\end{array}$ & $\begin{array}{l}-0.297^{* * *} \\
(0.008)\end{array}$ & $\begin{array}{l}-0.106 * * \\
(0.039)\end{array}$ & $\begin{array}{l}-0.112^{*} \\
(0.070)\end{array}$ & $\begin{array}{l}-0.259 * * \\
(0.010)\end{array}$ & $\begin{array}{l}-0.367^{* *} \\
(0.047)\end{array}$ & $\begin{array}{l}-0.293^{* *} \\
(0.014)\end{array}$ & $\begin{array}{l}-0.249 * * * \\
(0.001)\end{array}$ & $\begin{array}{l}-0.270^{* *} \\
(0.024)\end{array}$ & $\begin{array}{l}-0.2388^{* *} \\
(0.034)\end{array}$ \\
\hline Reg10 & $\begin{array}{l}-0.040 \\
(0.802)\end{array}$ & $\begin{array}{l}-0.030 \\
(0.884)\end{array}$ & - & - & - & $\begin{array}{l}0.236 \\
(0.167)\end{array}$ & $\begin{array}{l}0.178 \\
(0.201)\end{array}$ & - & - & - \\
\hline Obs. & 299 & 299 & 299 & 299 & 302 & 299 & 299 & 299 & 299 & 302 \\
\hline $\operatorname{AR}(1)$ & $\begin{array}{l}-2.68 \\
(0.007)\end{array}$ & $\begin{array}{l}-2.70 \\
(0.007)\end{array}$ & $\begin{array}{l}-3.16 \\
(0.002)\end{array}$ & $\begin{array}{l}-3.06 \\
(0.002)\end{array}$ & $\begin{array}{l}-3.10 \\
(0.002)\end{array}$ & $\begin{array}{l}-2.58 \\
(0.010)\end{array}$ & $\begin{array}{l}-1.88 \\
(0.060)\end{array}$ & $\begin{array}{l}-3.12 \\
(0.002)\end{array}$ & $\begin{array}{l}-3.49 \\
(0.000)\end{array}$ & $\begin{array}{l}-3.59 \\
(0.000)\end{array}$ \\
\hline $\mathrm{AR}(2)$ & $\begin{array}{l}-0.82 \\
(0.414)\end{array}$ & $\begin{array}{l}-1.23 \\
(0.218)\end{array}$ & $\begin{array}{l}-1.08 \\
(0.281)\end{array}$ & $\begin{array}{l}-0.95 \\
(0.341)\end{array}$ & $\begin{array}{l}-0.88 \\
(0.381)\end{array}$ & $\begin{array}{l}-1.11 \\
(0.269)\end{array}$ & $\begin{array}{l}-1.52 \\
(0.128)\end{array}$ & $\begin{array}{l}-0.81 \\
(0.420)\end{array}$ & $\begin{array}{l}-0.83 \\
(0.409)\end{array}$ & $\begin{array}{l}-1.01 \\
(0.310)\end{array}$ \\
\hline Instr. & 22 & 22 & 22 & 22 & 22 & 22 & 22 & 22 & 20 & 20 \\
\hline Sargan test & $\begin{array}{l}1.11 \\
(0.575)\end{array}$ & $\begin{array}{l}1.32 \\
(0.724)\end{array}$ & $\begin{array}{l}1.45 \\
(0.693)\end{array}$ & $\begin{array}{l}1.92 \\
(0.751)\end{array}$ & $\begin{array}{l}2.83 \\
(0.726)\end{array}$ & $\begin{array}{l}1.51 \\
(0.825)\end{array}$ & $\begin{array}{l}1.62 \\
(0.654)\end{array}$ & $\begin{array}{l}1.08 \\
(0.898)\end{array}$ & $\begin{array}{l}1.50 \\
(0.682)\end{array}$ & $\begin{array}{l}1.73 \\
(0.785)\end{array}$ \\
\hline Hansen test & $\begin{array}{l}0.28 \\
(0.868)\end{array}$ & $\begin{array}{l}0.84 \\
(0.840)\end{array}$ & $\begin{array}{l}0.43 \\
(0.934)\end{array}$ & $\begin{array}{l}0.79 \\
(0.940)\end{array}$ & $\begin{array}{l}1.97 \\
(0.853)\end{array}$ & $\begin{array}{l}1.20 \\
(0.879)\end{array}$ & $\begin{array}{l}1.64 \\
(0.650)\end{array}$ & $\begin{array}{l}0.38 \\
(0.984)\end{array}$ & $\begin{array}{l}1.75 \\
(0.625)\end{array}$ & $\begin{array}{l}2.22 \\
(0.695)\end{array}$ \\
\hline
\end{tabular}

${ }^{*},{ }^{* *},{ }^{* * *}$ significant at $10 \%, 5 \%$ and $1 \%$, respectively. The $p$-values are reported between parentheses.

$E\left(\varepsilon_{i}\right)=0 ; E\left(\mu_{i t}\right)=0 ; E\left(\varepsilon_{i} \mu_{i t}\right)=0$

And that time-varying errors are assumed uncorrelated:

$E\left(\mu_{i t} \mu_{i s}\right)=0 \quad$ witht $\neq s$

for $i=1, \ldots, 23$ and $t, s=2000, \ldots, 2014$.

Note that following Soto [37] no condition is imposed on the variance of $u_{i t}$, as the moment conditions used to estimate the model do not require homoscedasticity.

In the different models estimated the vector of explanatory variables $\mathrm{X}_{\mathrm{it}}$ comprises a subset of $\left\{1 . G D P p c_{i t}\right.$, l. ECHpc $c_{i t}$, l. GASp $p_{t}$, 1. GGEpc $\left.c_{i t}, E C G_{i t}, R E S e_{i t}, L i b_{i t}, R e g 10_{i}\right\}$ where the l. means that the variable is logarithmized. ${ }^{6}$

Table 2 summarizes the results for a number of different specifications. ${ }^{7}$

First, following Roodman [35], it should be clarified that all the specifications have less instruments than cross-groups to avoid over specification that may bias the statistics of the instrument validity tests. It should be noted that, according to Soto [37], the restriction to render instruments inferior to the number of cross-groups does not hinder the properties of the estimators when $\mathrm{N}$ is so small that it is not possible to exploit the full set of linear moment conditions, as is the case with the dataset used in the current study.

As for the specification tests none of the models fail them. All reject

\footnotetext{
${ }^{6}$ However, we should note that the gas price is country invariant and therefore we cannot include this variable simultaneously with the time dummies, so we exclude the time dummies whenever the $\mathrm{l}_{\text {. GASp }}$ is present in the regression.

${ }^{7}$ For robustness we estimated, also, all the different models including a dummy to control for the change in the methodology of measuring the electricity price (which was always not significant) and without the gas price and including the time dummies as they make the assumption of no correlation across individuals in the idiosyncratic disturbances more likely to hold - see, Roodman [35]. The results obtained were similar to the ones reported.
}

the null hypothesis of AR(1), showing that in fact the correct specification is a dynamic model. Also, all of them do not reject the null hypothesis of the AR(2), the Sargan and the Hansen tests. The results of the AR(2) test show that no further autocorrelation is present in the model after introducing the lag of the dependent variable and the Hansen and Sargan tests confirm the validity of the instruments used in each model.

As for the determinants of the electricity price, the two variables that control economic activity (l. GDPpc and l. ECHpc) cannot be at the same time in the regressions due to the high correlation between them which causes multicollinearity problems. When we consider them individually they are significant, however the Electricity Consumption of Households per capita (ECHpc) is robust across regressions while GDP per capita is only significant when we omit other non-significant variables. Anyway the point estimates of the elasticity for the GDPpc vary between 0.142 and 0.188 , while the ones for the ECHpc are slightly higher, with an interval range between 0.164 and 0.301 .

As for the supply factors, we highlight that the gas price impact is positive and robust across specifications and that the greenhouse emissions are not significant. Additionally, the share of renewable sources is robustly significant with a positive impact and a semielasticity point estimate between 0.965 and 1.73 , meaning that one percentage point increase of these sources on the overall share leads to relative increase in the electricity price between $0.965 \%$ and $1.73 \%{ }^{8}$

As for the market structure, the market concentration is not significant, while the impact of liberalization is robust across specifications with an estimated price reduction between $10.6 \%$ and $36.7 \%$. Finally, the variable that measures if there was still a regulated tariff in 2010 is consistently not significant. Nonetheless, we should note that this variable is a poor approximation of the impact of the end of the regulated

\footnotetext{
${ }^{8}$ Note that we measured the share of renewables from 0 ( $0 \%$ share) to 1 ( $100 \%$ share), therefore a share increase of $1 \mathrm{pp}$ means that the variable used varies 0,01 .
} 
market, and thus it remains challenging to generalize that it does not impact the price. What can be said is that the countries that ended the regulated tariff earlier do not have a higher household electricity price.

Comparing these results with the ones obtained by Moreno et al. [29], although some results are coincident (namely the effect of economic activity and the share of RES-E) there are some striking differences: first, and more important, as we included the exact date of liberalization rather than using the ECG as a proxy, we obtained that the liberalization process lowered the prices while, both, the ECG and GGE had no effect on them.

\section{Conclusions}

This paper has investigated the impact of several economic variables on household electricity prices by using econometric panel data techniques, namely the GMM proposal method by Blundell and Bond [4] with the Windermeijer (2005) [41] correction, in the framework of a controversial debate on the actual consequence of electricity market liberalization and the increased deployment of RES-E on electricity prices. Hence, we focused on the market opening of the generation segment of the electricity industry value chain, as it is the segment where most progress was to be expected since the first set of European directives. This feature can affect the consumer electricity prices as retail markets transfer electricity from the wholesale to the retail level.

The trend towards deregulation has been shared by the electricity industry and other network industries. Whereas empirical evidence generally suggests that deregulation has had a positive impact on efficiency and consumer welfare in telecommunications and air travel for example, the results expected for the electricity sector are much more ambiguous so far. One of the reasons that previous studies highlight, confirmed by the results from the models estimations herein presented, resides in the fact that not all the countries have fully completed their deregulation process. It was also possible to show that factors external to the deregulation process in the strict sense cause interference.

In a large number of European countries, price regulation still exists, especially for the household segment where not much progress can be seen; this may be because the European Directives leave room for interpretation regarding price regulation. In fact, as stated in ERGEG [12], a recent judgment of the Court of Justice of the European Union (Case 265/08, 20 April 2010) confirms that end-user price regulation, under certain restrictive conditions, can be, as a temporary measure, in compliance with the Directives.

In the current study several factors were found influencing household electricity prices that are common to all European Member-States. As for the supply factors is the overall activity measured by the GDP that influences the prices and not the household consumption, as for supply factors, as expected, the oil price has a significant impact on electricity prices as well as the share of renewable sources. Finally, in terms of market regulation we should note that gas emissions and the fact that a country being an earlier or later quitter of the regulated market do not have any impact on the prices. On the contrary, market concentration has a significant positive impact and liberalization has a significant negative impact on prices.

These results show that the current trend of increased market liberalization (which in some cases comes with new market actors and a decrease in concentration) has had the desired decrease on household electrical prices, while the end of regulated prices did not have any adverse impact on the price paid by households.

\section{Acknowledgments}

The first author would like to acknowledge that this work has been partially supported by the Portuguese Foundation for Science and Technology under project grant UID/MULTI/00308/2013. This work has been partially financed by the ERDF - European Regional Development Fund through the Operational Programme for Competitiveness and Internationalisation - COMPETE 2020 Programme, and by National Funds through the Portuguese funding agency, FCT - Fundação para a Ciência e a Tecnologia, within project SAICTPAC/0004/2015- POCI-01-0145-FEDER-016434.

\section{Appendix A}

See Table 3.

Table 3

Data availability on electricity price, market share of bigger producer, date of market liberalization and regulated market until in 2010.

\begin{tabular}{|c|c|c|c|c|}
\hline & $E p$ & ECG & Lib & $\operatorname{Reg} 10^{\mathrm{a}}$ \\
\hline Belgium & 2000-2014 & 2000-2014 & 2007 & No \\
\hline Czech R. & $2000-2014$ & 2000-2014 & 2006 & No \\
\hline Denmark & $2000-2014$ & 2000-2014 & 2003 & Yes \\
\hline Germany & 2000-2014 & 2000-2014 & 1998 & No \\
\hline Estonia & 2002-2014 & 2000-2014 & 2009 & Yes \\
\hline Ireland & 2000-2014 & 2000-2014 & 2005 & Yes \\
\hline Greece & 2000-2014 & 2000-2014 & July/2007 & Yes \\
\hline Spain & 2000-2014 & 2000-2014 & 2003 & Yes \\
\hline France & 2000-2014 & 2000-2014 & July/2007 & Yes \\
\hline Italy & 2000-2014 & 2000-2014 & July/2007 & Yes \\
\hline Cyprus & $2000-2014$ & $2000-2014$ & - & Yes \\
\hline Latvia & 2004-2014 & 2000-2014 & July/2007 & Yes \\
\hline Lithuania & 2004-2014 & 2000-2014 & July/2007 & Yes \\
\hline Hungary & 2000-2014 & 2000-2014 & July/2007 & Yes \\
\hline Malta & 2000-2014 & 2000-2014 & - & Yes \\
\hline Poland & 2001-2009 & 2000-2014 & July/2007 & Yes \\
\hline Portugal & $2000-2014$ & 2000-2014 & 2006 & Yes \\
\hline Romania & 2005-2014 & 2004-2009 & July/2007 & Yes \\
\hline Slovenia & 2000-2014 & 2002-2009 & July/2007 & No \\
\hline Slovakia & 2004-2014 & 2000-2014 & July/2007 & Yes \\
\hline Finland & 2000-2014 & 2000-2014 & 1997 & No \\
\hline Sweden & 2000-2014 & 2000-2014 & 1996 & No \\
\hline UK & 2000-2014 & 2000-2013 & 1990 & No \\
\hline
\end{tabular}

\footnotetext{
a Sources: Eurostat ERCEG 2010 and ACER Market Monitoring Report 2015.
} 


\section{References}

[1] ACER. Annual Report on the Results of Monitoring the Internal Electricity and Natural Gas Markets in 2014. Retreived 22nd September 2016 〈http://www.acer. europa.eu/official_documents/acts_of_the_agency/publication/acer_market_ monitoring_report_2015.pdf); 2015.

[2] Amorim F, Vasconcelos J, Abreu I, Silva PP, Martins V. How much room for a competitive electricity generation market in Portugal. Renew Sustain Energy Rev 2013;18:103-19.

[3] Ballester C, Furió D. Effects of renewables on the stylized facts of electricity prices. Renew Sustain Energy Rev 2015;52:1596-609.

[4] Blundell R, Bond S. Initial conditions and moments restrictions in dynamic panel data models. J Econ 1998;87:115-43.

[5] Bruno G. Approximating the bias of the LSDV estimator for dynamic unbalanced panel data models. Econ Lett 2005;87(3):361-6.

[6] Coppen F, Vivet D. The single European electricity market: a long road to convergence. National Bank of Belgium; 2006, (WP 84).

[7] Creutzig F, Christoph J, Lehmann P, Schmid E, Blücher F, Von , Breyer C, Fernandez B, Jakob M, Knopf B, Lohrey S, Susca T, Wiegandt K. Catching two European birds with one renewable stone: Mitigating climate change and Eurozone crisis by an energy transition renew. Sustain Energy Rev 2014;38:1015-28.

[8] Cruciani M. Évolution des prix de l'électricité aux clients domestiques en Europe occidentale, Note de L'Iffri, Novembre 2011, Gouvernance européenne et géopolitique de l'énergie, 1112011.

[9] Dillig M, Jung M, Karl J. The impact of renewables on electricity prices in Germany - An estimation based on historic spot prices in the years 2011-2013. Renew Sustain Energy Rev 2016;57:7-15.

[10] Erdogdu E. Electricity Market Reform: Lessons for developing countries. MPRA Working Paper 27317; 2010.

[11] Erdogdu E. The Impact of Power Market Reforms on Electricity Price-cost Margins and Cross-Subsidy Levels: A cross country panel data analysis. MPRA Working Paper 28414; 2011.

[12] ERGEG. Status review of End-User Price Regulation as of 1 January 2010, E10CEM-34-03. Available online (9/01/2013)at: 〈http://www.energy-regulators.eu/ $\rangle$; 2010.

[13] Ernst \& Young. Final Report Research Project: the Case for Liberalization. Available online (9/01/2013)at: 〈http://www.dti.gov.uk/files/file28401.pdf); 2006.

[14] European Commission (2012) Quarterly report on european electricity markets DG energy market observatory for energy, 5 (1): January 2012 - March 2012.

[15] European Parliament, European Council. Directive. 2001/77/EC of the European Parliament and the Council of 27 September 2001 on the promotion of electricity produced from renewable energy sources in the internal electricity market. L283/ 33-40. Brussels; 2001.

[16] European Parliament, European Council. Directive. 2003/54/EC of the European Parliament and of the Council of 26 June 2003 concerning common rules for the internal market in electricity and repealing Directive 96/92/EC2003/54/EC. Brussels; 2003.

[17] European Parliament, European Council. Directive. 2009/28/EC of the European Parliament and of the Council of 23 April 2009 on the promotion of the use of energy from renewable sources and amending and subsequently repealing Directives 2001/77/EC and 2003/30/EC. Brussels; 2009.

[18] European Parliament, European Council. Directive. 96/92/EC of the European Parliament and of the Council of 19 December 1996 concerning common rules for the internal market in electricity. Brussels; 1996.

[19] Fiorio C, Florio M. Would you say that the price you pay for electricity is fair? Consumers' satisfaction and utility reforms in the EU15. Energy Econ 2011;33:178-87.
[20] Florio M. energy reforms and Consumer prices in the EU over twenty year. Econ Energy Environ Policy 2014;3:37-52.

[21] Freitas C, Pereira da Silva P. Evaluation of dynamic pass-through of carbon prices into electricity prices - a cointegrated VECM analysis. Int J Public Policy 2013;9(1/ 2):65-85.

[22] Freitas C, Pereira da Silva P. European Union emissions trading scheme impact on the Spanish electricity price during phase II and phase III implementation". Uti Policy 2015;33:54-62.

[23] Hattori T, Tsutsui M. Economic impact of regulatory reforms in the electricity supply industry: a panel data analysis for OECD countries. Energy Policy 2004;32:823-32.

[24] Hyland M. Restructuring European electricity markets e A panel data analysis. Util Policy 2016;38:33-42.

[25] Jamasb T, Newbery D, Pollitt M. Core Indicators for Determinants and Performance of Electricity Sector Reform in Developing Countries. Cambridge Working Papers in Economics, CWPE 0438; 2004.

[26] Jasmab T, Pollit M. Electricity market reform in the European Union: review of Progress toward liberalization \& integration. Energy J 2005;26:11-41.

[27] Joskow PL. Lessons learned from electricity market liberalization. Energy J 2008:9-42.

[28] Kais S, Sami H. An econometric study of the impact of economic growth and energy use on carbon emissions: panel data evidence from fifty-eight countries. Renew Sustain Energy Rev 2016;59(C):1101-10.

[29] Moreno B, Lopez AJ, Garcia-Alvarez MT. The electricity prices in the European Union. The role of renewable energies and regulatory electric market reforms. Energy 2012;48:307-13.

[30] Nagayama H. Effects of regulatory reforms in the electricity supply industry on electricity prices in developing countries. Energy Policy 2007;35:3440-62.

[31] Nagayama H. Electric power sector reform liberalization models andelectric power prices in developing countries: an empirical analysis using international panel data. Energy Econ 2009;31:463-72.

[32] Oliveira C, Silva PP, Coelho D. Two decades of economic policy-making in Portugal: revisiting the energy arena in the wake of a recession. In Portugal: Economic, Political and Social Issues, ed. Gonçalves, A. e Vieira, A., 25-60. USA: Nova Publishers; 2012.

[33] Ortega-Izquierdo M, Del Río P. Benefits and costs of renewable electricity in Europe. Renew Sustain Energy Rev 2016;61:372-83.

[34] Pollitt M. Evaluating the evidence on electricity reform: Lessons for the South East Europe (SEE) market. Util Policy 2009;17:13-23.

[35] Roodman D. A note on the theme of too many instruments. Oxford Bulletin of Economics and Statistics, Department of Economics, 71. University of Oxford; 2009. p. 135-58.

[36] Silva PP, Soares I. EU spot prices and industry structure: assessing electricity market integration. Int J Energy Sect Manag 2008;2:340-50.

[37] Soto M. System GMM Estimation With A Small Sample,"UFAE and IAE Working Papers 780.09, Unitat de Fonaments de l'Anàlisi Econòmica (UAB) and Institut d'Anàlisi Econòmica (CSIC); 2009.

[38] Steiner F. Regulation, industry structure and performance in the electricity supply industry. OECD Economics Studies. OECD; 2001.

[39] Streimikiene D, Siksnelyte I. Electricity market opening impact on investments in electricity sector. Renew Sustain Energy Rev 2014;29:891-904.

[40] Thomas S. Recent evidence on the impact of electricity liberalisation on consumer prices, Public Services International Research Unit (PSIRU); 2006.

[41] Windmeijer F. A finite sample correction for the variance of linear efficient two-step GMM estimators. J Econ 2005;126:25-51.

[42] Winkler J, Gaio A, Pfluger B, Ragwitz M. Impact of renewables on electricity markets - Do support schemes matter?. Energy Policy 2016;93:157-67. 